\title{
Synthesis, X-Ray Crystal Structures and Catalytic Epoxidation of Oxidovanadium(V) Complexes with Aroylhydrazone and Ethyl Maltolate Ligands
}

\author{
Dong-Hui Zou, ${ }^{1,}{ }^{*}$ Min Liang ${ }^{2}$ and Wei Chen ${ }^{2}$ \\ ${ }^{1}$ College of Food and Bio-Engineering, Qiqihar University, Qiqihar 161006, P. R. China \\ ${ }^{2}$ School of Chemistry and Chemical Engineering, Qiqihar University, Qiqihar 161006, P. R. China \\ *Corresponding author: E-mail: zoudongh1000@163.com
}

Received: 11-30-2020

\begin{abstract}
Two oxidovanadium $(\mathrm{V})$ complexes, $\left[\mathrm{VOL}^{1} \mathrm{~L}\right](\mathbf{1})$ and $\left[\mathrm{VOL}^{2} \mathrm{~L}\right](2)(\mathrm{L}=$ ethyl maltolate), derived from the aroylhydrazones 4-bromo- $N^{\prime}$-(2-hydroxy-5-methylbenzylidene)benzohydrazide $\left(\mathrm{H}_{2} \mathrm{~L}^{1}\right)$ and $N^{\prime}$-(3,5-dibromo-2-hydroxybenzylidene)-4-methoxybenzohydrazide $\left(\mathrm{H}_{2} \mathrm{~L}^{2}\right)$, respectively, have been synthesized and characterized by elemental analysis, infrared and electronic spectroscopy. Structures of the complexes were further confirmed by single crystal X-ray determination. The $\mathrm{V}$ atoms in the complexes are coordinated by the ONO donor atoms of the aroylhydrazone ligand, OO donor atoms of the ethyl maltolate ligand, and one oxido $\mathrm{O}$ atom, forming octahedral coordination. The complexes function as effective olefin epoxidation catalysts with hydrogen peroxide as terminal oxidant and sodium hydrogen carbonate as a co-catalyst.
\end{abstract}

Keywords: Aroylhydrazone; vanadium complex; catalytic activity; crystal structure

\section{Introduction}

Schiff base complexes have gained remarkable attention due to their interesting applications in the development of new materials like catalysts, and biological applications like DNA cleavage, antibacterial, antiviral and antifungal agents. ${ }^{1}$ Metal complexes of hydrazone type Schiff bases were used as catalysts for the organic synthesis, such as olefin polymerization and epoxidation reactions. ${ }^{2}$ Among the various metal ions, the complexes of vanadium have received considerable interest in their biochemical significance and industrial catalytic processes. ${ }^{3}$ For instance, the use of vanadium complexes in asymmetric synthesis, in $\mathrm{C}-\mathrm{C}$ bond formation as well as in $\mathrm{C}-\mathrm{C}$, $\mathrm{C}-\mathrm{O}$ and $\mathrm{C}-\mathrm{H}$ bond cleavages, catalytic oxidation of various olefins, oxidative halogenation and selective epoxidation of unsaturated hydrocarbons and allyl alcohols. ${ }^{4}$ Aroylhydrazones bearing typical $-\mathrm{CO}-\mathrm{NH}-\mathrm{N}=\mathrm{CH}-$ group are interesting ligands in the preparation of various metal complexes which have considerable biological and catalytic properties. ${ }^{5}$ To date, a number of vanadium complexes have been obtained. However, the vanadium complexes with hydrazones are rarely reported with catalytic oxidation of olefins. Recently, our research group has reported some vanadium complexes and their catalytic epoxidation property. ${ }^{6}$ As a continuation of such work, we report in this paper two new vanadium $(\mathrm{V})$ complexes $\left[\mathrm{VOL}^{1} \mathrm{~L}\right](\mathbf{1})$ and $\left[\mathrm{VOL}^{2} \mathrm{~L}\right](2)(\mathrm{L}=$ ethyl maltolate), derived from the aroylhydrazones 4-bromo- $N^{\prime}$-(2-hydroxy-5-methylbenzylidene)benzohydrazide $\left(\mathrm{H}_{2} \mathrm{~L}^{1}\right)$ and $N^{\prime}$-(3,5-dibromo-2-hydroxybenzylidene)-4-methoxybenzohydrazide $\left(\mathrm{H}_{2} \mathrm{~L}^{2}\right)$.

\section{Experimental}

\section{1. Materials and Methods}

5-Methylsalicylaldehyde, 3,5-dibromosalicylaldehyde, 4-bromobenzohydrazide and 4-methoxybenzohydrazide were purchased from Sigma-Aldrich. $\mathrm{VO}(\mathrm{acac})_{2}$ and the solvents with analytical reagent grade were purchased from Xiya Chemicals Co. Ltd. Microanalyses for C, $\mathrm{H}, \mathrm{N}$ were carried out using a Perkin Elmer $2400 \mathrm{CHNS} / \mathrm{O}$ elemental analyzer. ${ }^{1} \mathrm{H}$ NMR spectra were recorded on a Bruker AVANCE $500 \mathrm{MHz}$ spectrometer. FT-IR spectra were recorded on a FT-IR 8400 -Shimadzu as $\mathrm{KBr}$ discs in 
the range of $400-4000 \mathrm{~cm}^{-1}$. UV-Vis spectra were recorded on a Lambda 35 spectrometer. X-ray diffraction data were collected using a Bruker Smart 1000CCD diffractometer.

\section{2. Synthesis of 4-bromo- $N$ '-(2-hydroxy- 5-methylbenzylidene)benzohydrazide $\left(\mathrm{H}_{2} \mathrm{~L}^{\mathbf{1}}\right)$}

An ethanolic solution $(20 \mathrm{~mL})$ containing 2-hydroxy-5-methylbenzaldehyde ( $1.0 \mathrm{mmol}, 0.14 \mathrm{~g}$ ) was added dropwise to an ethanolic solution of 4-bromobenzohydrazide $(1.0 \mathrm{mmol}, 0.22 \mathrm{~g})$ with constant stirring. The mixture was refluxed for $30 \mathrm{~min}$, after which the solvent was removed by rotary evaporator. The white precipitate was re-crystallized from ethanol and obtained by filtration. Yield: $0.25 \mathrm{~g}$, $76 \%$. For $\mathrm{C}_{15} \mathrm{H}_{13} \mathrm{BrN}_{2} \mathrm{O}_{2}$ : anal. calcd., \%: C, 54.07; H, 3.93; N, 8.41. Found, \%: C, 54.26; H, 4.02; N, 8.32. FT-IR (KBr), $\mathrm{cm}^{-1}: v(\mathrm{OH}) 3427, v(\mathrm{NH}) 3241, v(\mathrm{CH})$ 2820-3100, $v(\mathrm{C}=\mathrm{O})$ 1645, v(C=N) 1612, v(C-O) 1157. UV-Vis data in ethanol $\left(\lambda, \mathrm{nm}\left(\varepsilon, \mathrm{M}^{-1} \mathrm{~cm}^{-1}\right)\right]: 231(19,270)$, 285 (18,125), 303 (17,430), 345 (12,653). ${ }^{1} \mathrm{H}$ NMR $(500$ MHz, DMSO- $d^{6}$, ppm): $\delta=12.03(\mathrm{~s}, 1 \mathrm{H} ; \mathrm{OH}), 11.12(\mathrm{~s}, 1 \mathrm{H}$; $\mathrm{NH}), 8.62(\mathrm{~s}, 1 \mathrm{H} ; \mathrm{CH}=\mathrm{N}), 7.87$ (d, 2H; $\operatorname{ArH}), 7.73$ (d, 2H; $\operatorname{ArH}), 7.45$ (s, 1H, ArH), 7.12 (d, 1H; $\operatorname{ArH}), 6.95$ (d, 1H, $\mathrm{ArH}), 2.32\left(\mathrm{~s}, 3 \mathrm{H}, \mathrm{CH}_{3}\right)$.

\section{3. Synthesis of $N^{\prime}$-(3,5-dibromo- 2-hydroxybenzylidene)-4- methoxybenzohydrazide $\left(\mathrm{H}_{2} \mathrm{~L}^{2}\right)$}

An ethanolic solution $(20 \mathrm{~mL})$ containing 3,5-dibromo-2-hydroxybenzaldehyde ( $1.0 \mathrm{mmol}, 0.28 \mathrm{~g}$ ) was added dropwise to an ethanolic solution of 4-methoxybenzohydrazide $(1.0 \mathrm{mmol}, 0.17 \mathrm{~g})$ with constant stirring. The mixture was refluxed for $30 \mathrm{~min}$, after which the solvent was removed by rotary evaporator. The white precipitate was re-crystallized from ethanol and obtained by filtration. Yield: 0.31 g, $72 \%$. For $\mathrm{C}_{15} \mathrm{H}_{12} \mathrm{Br}_{2} \mathrm{~N}_{2} \mathrm{O}_{3}$ : anal. calcd., \%: C, 42.09; H, 2.83; N, 6.54. Found, \%: C, 41.85; H, 2.92; N, 6.46. FT-IR (KBr), $\mathrm{cm}^{-1}: v(\mathrm{OH}) 3447, v(\mathrm{NH}) 3221, v(\mathrm{CH}) 2820$ 3100, $v(\mathrm{C}=\mathrm{O}) 1653, v(\mathrm{C}=\mathrm{N}) 1612, v(\mathrm{C}-\mathrm{O}) 1153$. UV-Vis data in ethanol $\left(\lambda, \mathrm{nm}\left(\varepsilon, \mathrm{M}^{-1} \mathrm{~cm}^{-1}\right)\right]$ : $221(21,250), 272$ (17,610), 310 (15,455), 332 (16,820). ${ }^{1} \mathrm{H}$ NMR $(500 \mathrm{MHz}$, DMSO- $d^{6}$, ppm): $\delta=12.02$ (s, $\left.1 \mathrm{H} ; \mathrm{OH}\right), 11.13(\mathrm{~s}, 1 \mathrm{H} ; \mathrm{NH})$, $8.67(\mathrm{~s}, 1 \mathrm{H} ; \mathrm{CH}=\mathrm{N}), 7.88(\mathrm{~d}, 2 \mathrm{H} ; \operatorname{Ar} H), 7.79(\mathrm{~s}, 1 \mathrm{H} ; \operatorname{Ar} H)$, $7.71(\mathrm{~s}, 1 \mathrm{H}, \mathrm{ArH}), 7.13$ (d, 2H; $\mathrm{ArH}), 3.80\left(\mathrm{~s}, 1 \mathrm{H}, \mathrm{CH}_{3}\right)$.

\section{4. Synthesis of the complexes $\left[\mathrm{VOL}^{1} \mathrm{~L}\right](1)$ and $\left[\mathrm{VOL}^{2} \mathrm{~L}\right](2)$}

The aroylhydrazones $\mathrm{H}_{2} \mathrm{~L}^{1}(0.10 \mathrm{mmol}, 33 \mathrm{mg})$ or $\mathrm{H}_{2} \mathrm{~L}^{2}(0.10 \mathrm{mmol}, 43 \mathrm{mg})$ was dissolved in ethanol (15 $\mathrm{mL})$. To each solution an ethanolic solution $(10 \mathrm{~mL})$ of $\mathrm{VO}(\mathrm{acac})_{2}(0.10 \mathrm{mmol}, 26 \mathrm{mg})$ and ethyl maltol $(0.10$ $\mathrm{mmol}, 14 \mathrm{mg}$ ) was added with stirring. Mixtures were stirred at room temperature for $30 \mathrm{~min}$ to give deep brown solution. Brown block-shaped single crystals suitable for $\mathrm{X}$-ray analysis were obtained after slow evaporation of the solvent over a few days. The crystals were isolated by filtration.

Complex 1: Yield: 0.18 g, $33 \%$. For $\mathrm{C}_{22} \mathrm{H}_{18} \mathrm{BrN}_{2} \mathrm{O}_{6} \mathrm{~V}$ : anal. calcd., \%: C, 49.18; H, 3.38; N, 5.21. Found, \%: C, 49.35; H, 3.31; N, 5.12. FT-IR (KBr), $\mathrm{cm}^{-1}: v(\mathrm{C}=\mathrm{N}) 1611$, $v(\mathrm{C}-\mathrm{O}) 1176, v(\mathrm{~V}=\mathrm{O})$ 971. UV-Vis data in ethanol $(\lambda, \mathrm{nm}$ $\left(\varepsilon, \mathrm{M}^{-1} \mathrm{~cm}^{-1}\right)$ ]: 271 (18,223), $325(10,370), 410(2,738)$. Complex 2: Yield: $0.26 \mathrm{~g}, 41 \%$. For $\mathrm{C}_{22} \mathrm{H}_{17} \mathrm{Br}_{2} \mathrm{~N}_{2} \mathrm{O}_{7} \mathrm{~V}$ : anal. calcd., \%: C, 41.80; H, 2.71; N, 4.43. Found, \%: C, 41.61; H, 2.83; N, 4.51. FT-IR (KBr), $\mathrm{cm}^{-1}: v(\mathrm{C}=\mathrm{N}) 1608, v(\mathrm{C}-\mathrm{O})$ 1173, $v(\mathrm{~V}=\mathrm{O})$ 972. UV-Vis data in ethanol $(\lambda, \mathrm{nm}(\varepsilon$, $\left.\mathrm{M}^{-1} \mathrm{~cm}^{-1}\right)$ ]: $265(19,560), 332(12,451), 413(3,890)$.

\section{5. X-Ray Structure Determination}

Crystal structures of complexes were measured on a Bruker SMART 1000CCD diffractometer using Mo-Ka radiation $(\lambda=0.71073 \AA)$ and a graphite monochromator at $25{ }^{\circ} \mathrm{C}$. Unit cell and reflection data were obtained by standard methods and are summarized in Table $1 .^{7}$ The structures were solved, refined, and prepared for publication using the SHEXTL package (structure solution refinements and molecular graphics), ${ }^{8}$ and using full-matrix least-squares techniques by using $F^{2}$ with anisotropic displacement factors for all non-hydrogen atoms. The amino $\mathrm{H}$ atoms were located from difference Fourier maps and

Table 1. Crystal data and structure refinement for the complexes

\begin{tabular}{lcc}
\hline Parameters & $\mathbf{1}$ & $\mathbf{2}$ \\
\hline Molecular formula & $\mathrm{C}_{22} \mathrm{H}_{18} \mathrm{BrN}_{2} \mathrm{O}_{6} \mathrm{~V}$ & $\mathrm{C}_{22} \mathrm{H}_{17} \mathrm{Br}_{2} \mathrm{~N}_{2} \mathrm{O}_{7} \mathrm{~V}$ \\
Formula weight & 537.23 & 632.13 \\
Crystal system & Triclinic & Triclinic \\
Space group & $P-1$ & $P-1$ \\
$a(\AA)$ & $7.4116(9)$ & $9.7299(8)$ \\
$b(\AA)$ & $11.8466(11)$ & $11.1554(10)$ \\
$c(\AA)$ & $13.2718(12)$ & $11.4937(11)$ \\
$\alpha\left(^{\circ}\right)$ & $107.525(1)$ & $69.303(1)$ \\
$\beta\left(^{\circ}\right)$ & $93.496(1)$ & $88.575(1)$ \\
$\gamma\left({ }^{\circ}\right)$ & $90.253(1)$ & $88.952(1)$ \\
$V\left(\AA^{3}\right)$ & $1108.8(2)$ & $1166.6(2)$ \\
$Z$ & 2 & 2 \\
$D_{\text {calc }}\left(\mathrm{g} /\right.$ cm $\left.^{3}\right)$ & 1.609 & 1.800 \\
$\mu\left(\mathrm{mm}{ }^{-1}\right)$ & 2.290 & 3.897 \\
$F(000)$ & 540 & 624 \\
Reflections collected & 5921 & 10918 \\
Independent reflection & $4075(0.0134)$ & $4312(0.0405)$ \\
$\left(R_{\text {int }}\right)$ & & \\
Reflections observed & 3102 & 3227 \\
$(I>2 \sigma(I))$ & & $4312 / 0 / 309$ \\
Data/restraints/parameters & $4075 / 0 / 291$ & 1.049 \\
Goodness-of-fit on $F^{2}$ & 1.025 & $0.0399,0.0829$ \\
Final $R$ indices $(I>2 \sigma(I))$ & $0.0537,0.1333$ & $0.0644,0.0926$ \\
$R$ indices $($ all data $)$ & $0.0740,0.1465$ & $0.530,-0.449$ \\
Max/min $\mathrm{D} \rho\left(\mathrm{e} \AA^{-3}\right)$ & $1.034,-1.007$ & \\
\hline
\end{tabular}


refined isotropically, with $\mathrm{N}-\mathrm{H}$ distances restrained to 0.90(1) A. Positions of the remaining hydrogen atoms were calculated from the structure of the molecular skeleton and their displacement parameters were refined isotropically on a group-wise basis.

\section{Results and Discussion}

\section{1. Synthesis and Spectral Characterization}

The two complexes were readily prepared from the reaction of the corresponding aroylhydrazone ligands and $\mathrm{VO}(\mathrm{acac})_{2}$. The single crystals of the complexes are stable at ambient condition.

The $v(\mathrm{C}=\mathrm{N})$ absorptions are observed at $1611 \mathrm{~cm}^{-1}$ for 1 and $1608 \mathrm{~cm}^{-1}$ for $2 .^{9}$ The intense bands indicative of the $\mathrm{C}=\mathrm{O}$ vibrations and the sharp bands indicative of the $\mathrm{N}-\mathrm{H}$ vibrations are absent in the complexes, indicating the enolization of the aroylhydrazone ligands. The weak peaks in the low wave numbers in the region $450-700 \mathrm{~cm}^{-1}$ may be attributed to $\mathrm{V}-\mathrm{O}$ and $\mathrm{V}-\mathrm{N}$ bonds in the complexes. The complexes exhibit typical bands at $971-972 \mathrm{~cm}^{-1}$, which are assigned to the $\mathrm{V}=\mathrm{O}$ vibrations. ${ }^{10}$

The UV-Vis spectra of the complexes were recorded in $10^{-5} \mathrm{~mol} \mathrm{~L}^{-1}$ in ethanol, in the range $200-500 \mathrm{~nm}$. The weak bands centered at $325-332 \mathrm{~nm}$ for the complexes are attributed to intramolecular charge transfer transitions from the $p_{\pi}$ orbital on the nitrogen and oxygen to the empty $d$ orbitals of the metal. ${ }^{10}$ The intense bands observed at $265-270 \mathrm{~nm}$ are assigned to intraligand $\pi-\pi^{*}$ transition. The bands centered at about $410 \mathrm{~nm}$ are attributed to the ligand-to-metal charge transfer transitions (LMCT). ${ }^{11}$

\section{2. Structure Description of the Complexes}

The molecular structures of complexes $\mathbf{1}$ and $\mathbf{2}$ are shown in Figs. 1 and 2, respectively. Selected bond lengths

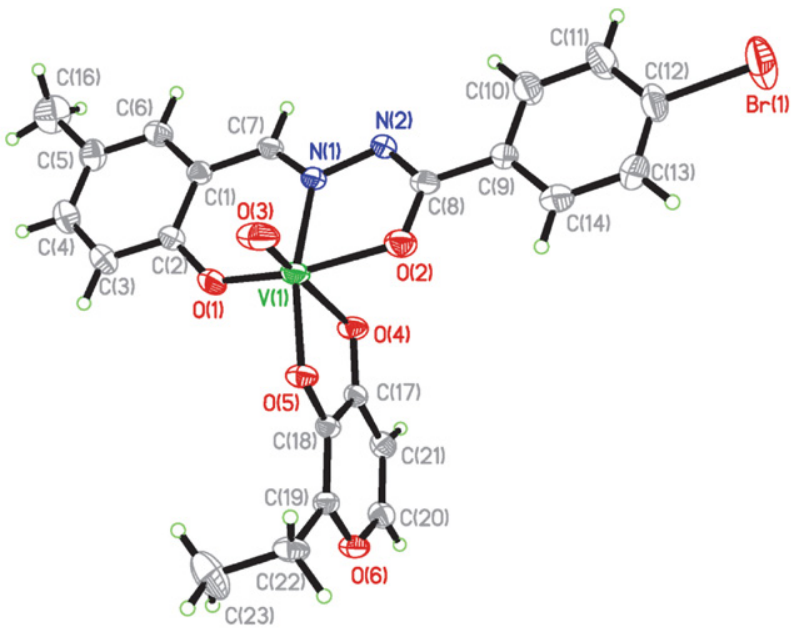

Fig. 1. An ORTEP diagram of complex 1 with atom labeling scheme and $30 \%$ probability thermal ellipsoids for all non-hydrogen atoms. and angles are reported in Table 2 . The $\mathrm{V}$ atoms in both complexes are six-coordinated in octahedral geometry, with the phenolate oxygen $(\mathrm{O}(1))$, the enolate oxygen $(\mathrm{O}(2))$ and the imine nitrogen $(\mathrm{N}(1))$ of the aroylhydrazone ligands, and the hydroxylate oxygen $(\mathrm{O}(5))$ of the ethyl maltolate ligand in the equatorial plane, and with the oxido group $(\mathrm{O}(3))$ and the carbonyl oxygen $(\mathrm{O}(4))$ in the axial positions. The $\mathrm{V}$ atoms deviated from the leastsquares planes defining by the four equatorial donor at-

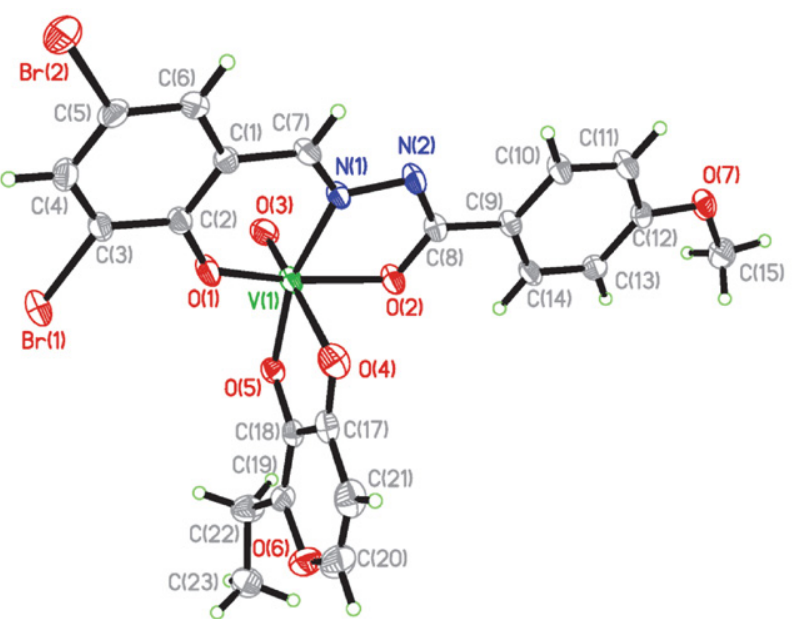

Fig. 2. An ORTEP diagram of complex 2 with atom labeling scheme and $30 \%$ probability thermal ellipsoids for all non-hydrogen atoms.

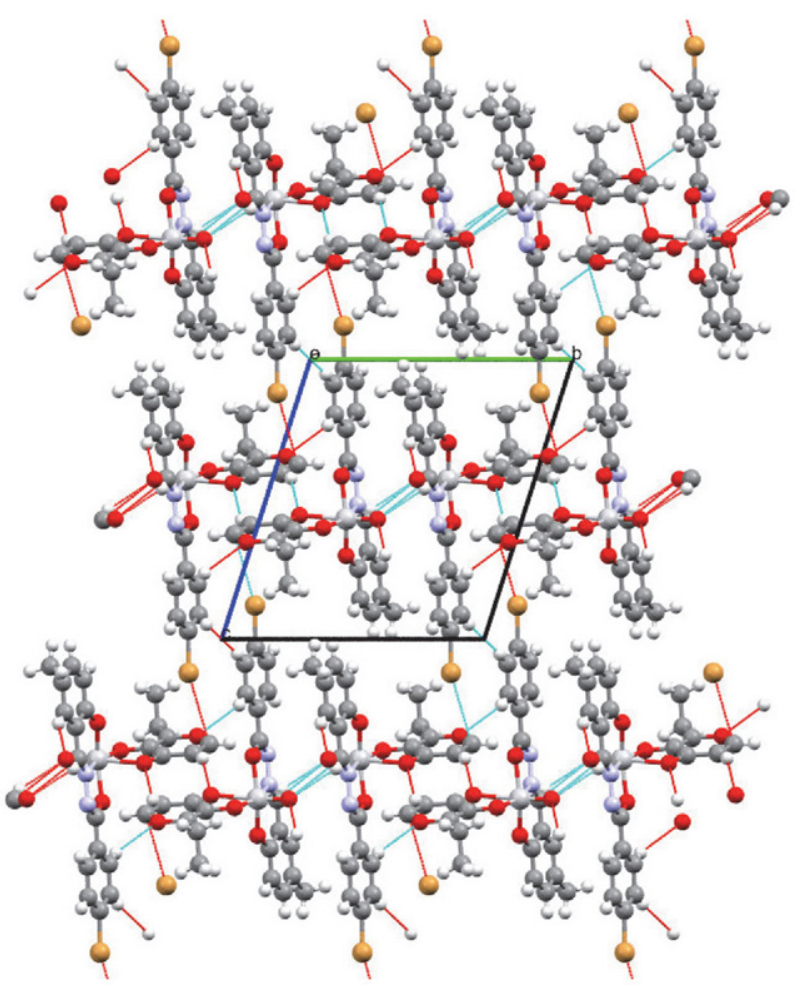

Fig. 3. Hydrogen bonds linked structures of complex 1, viewed along the $a$ axis. Hydrogen bonds are shown as dashed lines. 




Fig. 4. Hydrogen bonds linked structures of complex 2, viewed along the $a$ axis. Hydrogen bonds are shown as dashed lines.

oms by 0.295(2) $\AA$ for $\mathbf{1}$ and 0.290(2) $\AA$ for $\mathbf{2}$. The bond lengths related to the $\mathrm{V}$ atoms are comparable to the similar vanadium complexes. $^{6 \mathrm{~b}, 12}$ The benzene rings $\mathrm{C}(1)-\mathrm{C}(6)$ and $\mathrm{C}(9)-\mathrm{C}(14)$ form dihedral angles of 2.1(3) $)^{\circ}$ for 1 and $2.7(3)^{\circ}$ for 2 . There exists weak $\operatorname{Br}(1) \cdots \mathrm{O}(7)^{\mathrm{i}}(\mathrm{i}:-1+x, y, 1+z)$ contact with distance of 2.96(5) A representing $87.8 \%$ of the sum of van der Waals radia in complex 2 .

In the crystal structure of complex $\mathbf{1}$, the vanadium complex molecules are linked through $\mathrm{C}-\mathrm{H} \cdots \mathrm{O}$ hydrogen bonds (Table 3 ) to form layers along the $a b$ plane (Fig. 3). In the crystal structure of complex 2 , the vanadium complex molecules are linked through $\mathrm{C}-\mathrm{H} \cdots \mathrm{O}$ and $\mathrm{C}-\mathrm{H} \cdots \mathrm{Br}$ hydrogen bonds (Table 3 ) to form three-dimensional network (Fig. 4).
Table 2. Selected bond lengths $(\AA)$ and angles $\left(^{\circ}\right)$ for the complexes

\begin{tabular}{lrr}
\hline & $\mathbf{1}$ & \multicolumn{1}{c}{$\mathbf{2}$} \\
\hline Bond lengths $(\AA)$ & & \\
$\mathrm{V}(1)-\mathrm{O}(1)$ & $1.841(3)$ & $1.847(2)$ \\
$\mathrm{V}(1)-\mathrm{O}(3)$ & $1.580(3)$ & $1.583(3)$ \\
$\mathrm{V}(1)-\mathrm{O}(5)$ & $1.871(3)$ & $1.863(2)$ \\
$\mathrm{V}(1)-\mathrm{O}(2)$ & $1.941(3)$ & $1.921(2)$ \\
$\mathrm{V}(1)-\mathrm{O}(4)$ & $2.261(3)$ & $2.259(3)$ \\
$\mathrm{V}(1)-\mathrm{N}(1)$ & $2.097(3)$ & $2.090(3)$ \\
$\mathrm{Bond}$ angles $\left({ }^{\circ}\right)$ & & \\
$\mathrm{O}(3)-\mathrm{V}(1)-\mathrm{O}(1)$ & $100.96(19)$ & $99.93(13)$ \\
$\mathrm{O}(1)-\mathrm{V}(1)-\mathrm{O}(5)$ & $98.68(13)$ & $100.77(11)$ \\
$\mathrm{O}(1)-\mathrm{V}(1)-\mathrm{O}(2)$ & $155.11(14)$ & $154.62(11)$ \\
$\mathrm{O}(3)-\mathrm{V}(1)-\mathrm{N}(1)$ & $101.16(14)$ & $99.60(13)$ \\
$\mathrm{O}(5)-\mathrm{V}(1)-\mathrm{N}(1)$ & $160.03(12)$ & $160.64(12)$ \\
$\mathrm{O}(3)-\mathrm{V}(1)-\mathrm{O}(4)$ & $173.29(17)$ & $77.60(10)$ \\
$\mathrm{O}(5)-\mathrm{V}(1)-\mathrm{O}(4)$ & $77.53(10)$ & $84.41(11)$ \\
$\mathrm{N}(1)-\mathrm{V}(1)-\mathrm{O}(4)$ & $82.89(11)$ & $98.05(12)$ \\
$\mathrm{O}(3)-\mathrm{V}(1)-\mathrm{O}(5)$ & $97.98(14)$ & $97.23(12)$ \\
$\mathrm{O}(3)-\mathrm{V}(1)-\mathrm{O}(2)$ & $95.33(17)$ & $95.16(10)$ \\
$\mathrm{O}(5)-\mathrm{V}(1)-\mathrm{O}(2)$ & $97.53(12)$ & $83.99(11)$ \\
$\mathrm{O}(1)-\mathrm{V}(1)-\mathrm{N}(1)$ & $83.29(13)$ & $74.78(11)$ \\
$\mathrm{O}(2)-\mathrm{V}(1)-\mathrm{N}(1)$ & $75.14(12)$ & $83.34(11)$ \\
$\mathrm{O}(1)-\mathrm{V}(1)-\mathrm{O}(4)$ & $84.75(14)$ & $80.93(11)$ \\
$\mathrm{O}(2)-\mathrm{V}(1)-\mathrm{O}(4)$ & $80.45(12)$ & \\
\hline & &
\end{tabular}

\section{3. Catalytic Property}

The catalytic experiment was carried out according to the literature method. ${ }^{6 \mathrm{~b}} \mathrm{~A}$ mixture of $\mathrm{CH}_{3} \mathrm{OH} / \mathrm{CH}_{2} \mathrm{Cl}_{2}$ $(\mathrm{V}: \mathrm{V}=7: 3,1.2 \mathrm{~mL})$ was used for the reactions at $25^{\circ} \mathrm{C}$. The molar ratios for the catalyst:substrate: $\mathrm{NaHCO}_{3}: \mathrm{H}_{2} \mathrm{O}_{2}$ are 1:298:117:1170. The conversion was measured after 74.5 $\mathrm{min}$. Both vanadium complexes have good property in the olefin oxidation processes with epoxides as the products. The results are summarized in Table 4. Interestingly, both complexes have similar catalytic properties with high epoxide yields and good selectivity toward the aliphatic and aromatic substrates. However, when $\mathrm{H}_{2} \mathrm{O}_{2}$ was used as single oxidant the catalytic efficiency is not good. When $\mathrm{NaHCO}_{3}$ was added as a co-catalyst to the above reactions,

Table 3. Hydrogen bonding interactions $\left(\AA,^{\circ}\right)$

\begin{tabular}{lcccc}
\hline $\boldsymbol{D}-\mathbf{H} \cdots A$ & $\boldsymbol{d}(\boldsymbol{D}-\mathbf{H})$ & $\boldsymbol{d}(\mathbf{H} \cdots A)$ & $\boldsymbol{d}(\boldsymbol{D} \cdots \boldsymbol{A})$ & $\operatorname{Angle}(\boldsymbol{D}-\mathbf{H} \cdots A)$ \\
\hline $\mathbf{1}$ & & & & \\
$\mathrm{C}(6)-\mathrm{H}(6) \cdots \mathrm{O}(3)^{\mathrm{ii}}$ & 0.93 & $2.50(3)$ & $3.367(5)$ & $154(6)$ \\
$\mathrm{C}(7)-\mathrm{H}(7) \cdots \mathrm{O}(3)^{\mathrm{iii}}$ & 0.93 & $2.53(3)$ & $3.143(5)$ & $124(6)$ \\
$\mathrm{C}(14)-\mathrm{H}(14) \cdots \mathrm{O}(6)^{\mathrm{iv}}$ & 0.93 & $2.57(3)$ & $3.399(5)$ & $148(6)$ \\
$\mathrm{C}(21)-\mathrm{H}(21) \cdots \mathrm{O}(4)^{\mathrm{v}}$ & 0.93 & $2.42(3)$ & $3.246(5)$ & $148(6)$ \\
$\mathbf{2}$ & & & & \\
$\mathrm{C}(6)-\mathrm{H}(6) \cdots \mathrm{O}(3)^{\mathrm{vi}}$ & 0.93 & $2.56(3)$ & $3.237(4)$ & $130(5)$ \\
$\mathrm{C}(11)-\mathrm{H}(11) \cdots \mathrm{Br}(2)^{\mathrm{vii}}$ & 0.93 & $2.80(3)$ & $3.563(4)$ & $140(5)$ \\
$\mathrm{C}(19)-\mathrm{H}(19) \cdots \mathrm{O}(7)^{\text {viii }}$ & 0.93 & $2.47(3)$ & $3.340(4)$ & $156(5)$ \\
\hline
\end{tabular}

Symmetry codes: ii) $1+x, y, z$; iii) $1-x, 1-y, 1-z$; (iv) $-x,-y, 1-z$; (v) $1-x,-y, 1-z$; (vi) $-x, 1-y, 1-z$; (vii) $1+x,-1+y$, $z$; (viii) $x, y, 1+z$. 
Table 4. The catalytic oxidation results

\begin{tabular}{|c|c|c|c|}
\hline Substrate & Product & & $\begin{array}{l}\text { Conversion } \\
(\%)(\mathrm{TON})^{\mathrm{a}}\end{array}$ \\
\hline & & 1 & $>99(351)$ \\
\hline & & 2 & $>99(367)$ \\
\hline & & 1 & $98(343)$ \\
\hline & & 2 & $>99(327)$ \\
\hline & & 1 & $93(310)$ \\
\hline & & 2 & $96(307)$ \\
\hline & & 1 & 95 (282) \\
\hline & & 2 & $97(291)$ \\
\hline
\end{tabular}

${ }^{\mathrm{a}} \mathrm{TON}=(\mathrm{mmol}$ of product $) / \mathrm{mmol}$ of catalyst.

the efficiency of the catalytic property can increase obviously. This might be attributed to the equilibrium process between $\mathrm{H}_{2} \mathrm{O}_{2}$ and hydrogen carbonate to produce peroxymonocarbonate, $\mathrm{HCO}_{4}^{-}$, which is a more reactive nucleophile than $\mathrm{H}_{2} \mathrm{O}_{2}$ and facilitated the epoxidation reactions. The two vanadium complexes have better catalytic properties than the cobalt(II) complex derived from 2-bromo- $N$ '-(2-hydroxy-5-methylbenzylidene)benzohydrazide, ${ }^{13}$ and similar catalytic properties with the oxidovanadium $(\mathrm{V})$ and dioxidomolybdenum(VI) complexes of hydrazones and Schiff bases. ${ }^{14}$

\section{Conclusion}

Two new similar oxidovanadium(V) complexes with aroylhydrazone ligands have been prepared and structurally characterized using X-ray structure analysis. The complexes have octahedral geometry with positions around the central atom being occupied with donor atoms of the aroylhydrazone ligand, the ethyl maltolate ligand and one oxido group. The complexes show effective catalytic property in the oxidation of various olefins to their corresponding epoxides.

\section{Supplementary Material}

CCDC reference numbers 2043121 and 2043122 contain the supplementary crystallographic data for this article. These data can be obtained free of charge athttp:// www.ccdc.cam.ac.uk, or from Cambridge Crystallographic Data Center, 12Union Road, Cambridge CB2 1EZ, UK; Fax: +44 1223336 033; Email:deposit@ccdc.cam.ac.uk.

\section{Acknowledgments}

This work was financially supported by the Fundamental Research Funds in Heilongjiang Provincial Universities (Project No. 135409307).

\section{References}

1. (a) H. Zakeri, S. Rayati, G. Zarei, A. Parsa, F. Adhami, Iran. J. Catal. 2020,10, 71-78;

(b) M. Gillard, J. Weynand, H. Bonnet, F. Loiseau, A. Decottignies, J. M. Dejeu, E. Defrancq, B. Elias, Chem. Eur. J. 2020, 26, 13849-13860; DOI:10.1002/chem.202001409

(c) A. Arunadevi, N. Raman, J. Coord. Chem. 2020, 73, 20952116; DOI:10.1080/00958972.2020.1824293

(d) J. M. Galvan-Hidalgo, D. M. Roldan-Marchan, A. Gonzalez-Hernandez, T. Ramirez-Apan, A. Nieto-Camacho, S. Hernandez-Ortega, E. Gomez, Med. Chem. Res. 2020, 29, 2146-2156; DOI:10.1007/s00044-020-02630-4

(e) S. Kumari, S. Ray, New J. Chem. 2020, 44, 14953-14963; DOI:10.1039/D0NJ01590C

(f) S. Q. T. Pham, C. Richardson, C. Kelso, A. C. Willis, S. F. Ralph, Dalton Trans. 2020, 49, 10360-10379.

DOI:10.1039/D0DT01370F

2. (a) R. Ramachandran, G. Prakash, P. Viswanathamurthi, J. G. Malecki, Inorg. Chim. Acta 2018, 477, 122-129;

DOI:10.1016/j.ica.2018.03.007

(b) M. Ghorbanloo, A. M. Alamooti, J. Porous Mater. 2017, 24, 769-777; DOI:10.1007/s10934-016-0314-9

(c) S. Selvamurugan, R. Ramachandran, G. Prakash, P. Viswanathamurthi, J. G. Malecki, A. Endo, J. Organomet. Chem. 2016, 803, 119-127;

DOI:10.1016/j.jorganchem.2015.11.017

(d) S. Muthumari, R. Ramesh, RSC Advances 2016, 6, 5210152112; DOI:10.1039/C6RA06734D

(e) Y.-J. Cai, Y.-Y. Wu, F. Pan, Q.-A. Peng, Y.-M. Cui, Acta Chim.Slov. 2020, 67, 896-903; DOI:10.17344/acsi.2020.5895

(f) S. Aslkhademi, N. Noshiranzadeh, M. S. Sadjadi, K. Mehrani, N. Farhadyar, Polyhedron 2019, 160, 115-122.

DOI:10.1016/j.poly.2018.12.023

3. (a) J. Szklarzewicz, A. Jurowska, M. Hodorowicz, R. Grybos, K. Kruczala, M. Gluch-Lutwin, G. Kazek, J. Coord. Chem.2020, 73, 986-1008; (b) L.-P. Lu, F.-Z. Suo, Y.-L. Feng, L.-L. Song, Y. Li, Y.-J. Li, K.-T. Wang, Eur. J. Med. Chem. 2019, 176, 1-10; (c) F. Heidari, S. J. A. Fatemi, S. Y. Ebrahimipour, H. Ebrahimnejad, J. Castro, M. Dusek, V. Eigner, Inorg. Chem. Commun. 2017, 76, 1-4; (d) M. Sutradhar, L. M. D. R. S. Martins, M. F. C. Guedes da Silva, A. J. L. Pombeiro, Coord. Chem. Rev. 2015, 301-302, 200-239.

4. (a) L. Schober, M. Sako, S. Takizawa, H. Groger, H. Sasai, Chem. Commun. 2020, 56, 10151-10154;

DOI:10.1039/D0CC02621B

(b) U. Das, P. Pattanayak, M. K. Santra, S. Chattopadhyay, J. Chem. Res. 2018, 1, 57-62;

DOI:10.3184/174751918X15168821806597

(c) Y. Sekiguchi, K. Arashiba, H. Tanaka, A. Eizawa, K. Na- 
kajima, K. Yoshizawa, Y. Nishibayashi, Angew. Chem. Int. Ed. 2018, 57, 9064-9068; DOI:10.1002/anie.201802310

(d) M. R. Maurya, N. Jangra, F. Avecilla, I. Correia, Eur. J. Inorg. Chem. 2019, 2, 314-329; DOI:10.1002/ejic.201801243

(e) J. C. Pessoa, M. R. Maurya, Inorg. Chim. Acta 2017,455, 415-428. DOI:10.1016/j.ica.2016.04.012

5. (a) D. Sadhukhan, A. Ray, G. Pilet, C. Rizzoli, G. M.Rosair, C. J. Gomez-Garcia, S. Signorella, S. Bellu, S. Mitra, Inorg. Chem. 2011, 50, 8326-8339; DOI:10.1021/ic200846j

(b) M. Bagherzadeh, M. Zare, T. Salemnoush, S. Ozkar, S. Akbayrak, Appl. Catal. A-General 2014, 475, 55-62;

DOI:10.1016/j.apcata.2014.01.020

(c) V. Vrdoljak, J. Pisk, D. Agustin, P. Novak, J. P. Vukovic, D. Matkovic-Calogovic, New J. Chem. 2014, 38, 6176-6185;

DOI:10.1039/C4NJ01394H

(d) M. Ghorbanloo, R. Bikas, G. Malecki, Inorg. Chim. Acta 2016, 445, 8-16; DOI:10.1016/j.ica.2016.02.018

(e) Z. Moradi-Shoeili, M. Zare, S. Akbayrak, S. Ozkar, Transition Met. Chem. 2017, 42, 357-363.

DOI:10.1007/s11243-017-0139-7

6. (a) D.-H. Zou, N. Sun, W. Chen, J. Struct. Chem. 2019, 60, 1101-1109; DOI:10.1134/S0022476619070114

(b) M. Liang, D.-H. Zou, Acta Chim. Slov. 2016, 63, 180-185; DOI:10.17344/acsi.2015.2169

(c) M. Liang, D.-H. Zou, Inorg. Nano-Met. Chem. 2017, 47, 110-115; DOI:10.1080/15533174.2016.1149730

(d) M. Liang, N. Sun, D.-H. Zou, Acta Chim. Slov. 2018, 65, 964-969. DOI:10.17344/acsi.2018.4625

7. Bruker, SMART (Version 5. 624) and SAINT (Version 6. 04) programs using the windows NT system, Bruker AXS Inc., Madison, WI, USA, 2001.

8. G. M. Sheldrick, Acta Crystallogr. 2008, A64, 112-122. DOI: $10.1107 /$ S0108767307043930

9. D. Sadhukhan, M. Maiti, E. Zangrando, S. Pathan, S. Mitra, A. Patel, Polyhedron 2014, 69, 1-9.

DOI:10.1016/j.poly.2013.11.007
10. A. Sarkar, S. Pal, Polyhedron 2006, 25, 1689-1694. DOI:10.1016/j.poly.2005.11.009

11. S. Roy, T. N. Mandal, K. Das, R. J. Butcher, A. L. Rheingold, S. K. Kar, J. Coord. Chem. 2010, 63, 2146-2157. DOI:10.1080/00958972.2010.499457

12. (a) J.-X. Lei, J. Wang, Y. Huo, Z. You, Acta Chim. Slov. 2016, 63, 670-677;

(b) L. Xu, Y. Li, M. Duan, Y. Li, M. Han, J. Wu, Y. Wang, K. Dong, Z. You, Polyhedron 2019, 165, 138-142;

DOI:10.1016/j.poly.2019.03.016

(c) Q.-C. Zhou, T.-R. Wang, H. Li, L. Chen, J.-J. Xin, S. Guo, G.-H. Sheng, Z.-L. You, J. Inorg. Biochem. 2019, 196, 110680; DOI:10.1016/j.jinorgbio.2019.03.020

(d) Z.-Q. Sun, S.-F. Yu, X.-L. Xu, X.-Y. Qiu, Acta Chim. Slov. 2020, 67, 1281-1289; DOI:10.17344/acsi.2020.6236

(e) D. L. Peng, Russ. J. Coord. Chem. 2020, 46, 276-282; DOI:10.1134/S1070328420040065

(f) L. Li, K.-W. Lu, Y.-T. Li, G.-F. Jiang, Y. Xin, L. Ye, Y. Zhang, H. Liu, C.-N. Shang, Z.-L. You, Chin. J. Inorg. Chem. 2017, 33, 905-912; DOI:10.1007/s40242-017-7240-5

(g) Y. M. Cui, Y. Q. Wang, X. X. Su, H. Huan, P. Zhang, J. Struct. Chem. 2019, 60, 1299-1305.

DOI:10.1134/S0022476619080092

13. F.-M. Wang, Acta Chim. Slov. 2016, 63, 406-410. DOI:10.1109/TCSII.2015.2505038

14. (a) H.-Y. Liu, Y.-S. Yin, L.-J. Yang, X.-L. Zhou, Y.-F. Ye, Acta Chim. Slov. 2020, 67, 130-136; DOI:10.17344/acsi.2019.5286 (b) Q.-A. Peng, X.-P. Tan, Y.-D. Wang, S.-H. Wang, Y.-X. Jiang, Y.-M. Cui, Acta Chim. Slov. 2020, 67, 644-650; DOI:10.17344/acsi.2019.5650

(c) Q. Yang, P. Wang, Y. Lei, Acta Chim. Slov. 2020, 67, $927-$ 933; DOI:10.17344/acsi.2020.5932

(d) M. Abdi, A. F. Shojaei, M. Ghadermazi, Z. Moradi-Shoeili, Acta Chim. Slov. 2020, 67, 476-486.

DOI:10.17344/acsi.2019.5466

\section{Povzetek}

Sintetizirali smo dva oksidovanadijeva(V) kompleksa, [VOL $\left.{ }^{1} \mathrm{~L}\right](\mathbf{1})$ in $\left[\mathrm{VOL}^{2} \mathrm{~L}\right](2)$ ( $\mathrm{L}=$ etil maltolat), pripravljena $\mathrm{z}$ aroilhidrazonoma 4-bromo- $N^{\prime}$-(2-hidroksi-5-metilbenziliden)benzohidrazidom $\left(\mathrm{H}_{2} \mathrm{~L}^{1}\right)$ in $N^{\prime}$-(3,5-dibromo-2-hidroksibenzilidene)-4-methoksibenzohidrazidom $\left(\mathrm{H}_{2} \mathrm{~L}^{2}\right)$ ter ju okarakterizirali z elementno analizo, infrardečo in elektronsko spektroskopijo. Strukturi kompleksov smo nadalje potrdili z monokristalno rentgensko difrakcijo. Vanadijev atom $\mathrm{v}$ obeh kompleksih je koordiniran z ONO donorskimi atomi aroilhidrazonskega liganda, OO donorskimi atomi etil maltolatnega liganda in $\mathrm{z}$ enim oksido $\mathrm{O}$ atomom, ki skupaj tvorijo oktaedrično koordinacijo. Kompleksa sta učinkovita katalizatorja za epoksidacijo olefinov $\mathrm{z}$ vodikovim peroksidom kot oksidantom in natrijevim hidrogenkarbonatom kot kokatalizatorjem.

Except when otherwise noted, articles in this journal are published under the terms and conditions of the Creative Commons Attribution 4.0 International License 